\title{
Comparison of Direct Microbial Count Procedures for Planktonics and Sessiles Enumeration
}

\author{
Barbara Speranza, Angela Racioppo, Antonio Bevilacqua, Milena Sinigaglia, Clelia Altieri* \\ Department of the Science of Agriculture, Food and Environment (SAFE), University of Foggia, \\ Foggia, Italy \\ Email: ${ }^{*}$ clelia.altieri@unifg.it
}

Received 26 August 2014; revised 20 September 2014; accepted 9 October 2014

Copyright $@ 2014$ by authors and Scientific Research Publishing Inc.

This work is licensed under the Creative Commons Attribution International License (CC BY). http://creativecommons.org/licenses/by/4.0/

c) (i) Open Access

\begin{abstract}
In the present investigation, the sensitivity of different direct microbial count procedures applied on systems containing both planktonics and sessiles was tested. The direct count pour plate was compared with direct epifluorescent microscopic enumerations in order to evaluate the efficiency of the studied techniques in giving information about microbial activity or viability. Our results indicate that the standard plate count procedure is the most sensitive method to estimate viable and cultivable planktonic cells. On the other hand, direct enumeration by epifluorescent microscopy may become an interesting alternative to count sessile cells.
\end{abstract}

\section{Keywords}

Direct Viable Count, Biofilm, Epifluorescence Microscopy, Fluorochromes

\section{Introduction}

Accurate quantitative evaluations of bacterial populations, of biomass and of community structure are critical prerequisites for assessing the roles of bacteria in natural and technical systems (i.e. sewage or food processing plants). There is no scientific univocality on which procedure gives the best results in representing a viable microbial population. Plate count methods are often employed for microbiological quantitative analyses, but they are time consuming (because of required lengthy incubations) and typically do not provide useful information concerning microbial activity, or viability. Bacteria are generally physically removed (by filtration or dilution) from the native sample and are therefore no longer subject to possible inhibitory substances or conditions that

\footnotetext{
*Corresponding author.
}

How to cite this paper: Speranza, B., Racioppo, A., Bevilacqua, A., Sinigaglia, M. and Altieri, C. (2014) Comparison of Direct Microbial Count Procedures for Planktonics and Sessiles Enumeration. Food and Nutrition Sciences, 5, 2033-2037. 
may limit their metabolic activity in situ. Moreover, plate count procedures cannot be used to directly observe active cells in situ, especially when the cells are attached to suspended particulate matter or other solid surfaces (i.e. biofilm). In this case, a fundamental difficulty in efficient separating bacteria from their substratum lies in the conflict between using procedures hard enough to achieve both the near-complete detachment, and the cell wholeness. Consequently, opportune conditions need to be carefully chosen in order to maximize the detachment efficiency and minimize the cell damage. A variety of procedures have been proposed to directly count sessile cells in situ and these include direct counts by means of epifluorescence techniques [1] [2].

Our objective in the present investigation was to test the sensitivity of different procedures in counting bacteria, both as planktonics and sessiles. In particular, the results of the direct count pour plate were compared with those obtained by direct epifluorescent microscopic enumerations, in order to point out their effectiveness and accuracy in giving information about microbial activity or viability.

\section{Materials and Methods}

\subsection{Preparation of Samples}

One strain of Salmonella sp. purchased from a public collection (American Type Culture Collection, ATCC $35,664)$ was used in the present work. Prior to use, the culture was grown aerobically at $37^{\circ} \mathrm{C}$ for $24 \mathrm{~h}$ in Tryptone Soya Broth (TSB, Oxoid, Milan, Italy), composed as follows: $17 \mathrm{~g} / \mathrm{l}$ pancreatic digest of casein, $3.0 \mathrm{~g} / \mathrm{l} \mathrm{en-}$ zymatic digest of soya bean, $5.0 \mathrm{~g} / \mathrm{l}$ sodium chloride, $2.5 \mathrm{~g} / \mathrm{l}$ di-potassium hydrogen phosphate, $2.5 \mathrm{~g} / \mathrm{l}$ glucose $(\mathrm{pH} 7.3 \pm 0.2)$.

Planktonic Salmonella sp. samples were prepared pouring $20 \mathrm{ml}$ of TSB into sterile Coplin jars and inoculating each of them with $10^{3} \mathrm{CFU} / \mathrm{ml}$. Incubation was performed at $37^{\circ} \mathrm{C}$, without shaking, for 5 days.

Glass slides $(25.4 \mathrm{~mm} \times 76.2 \mathrm{~mm})$ were used as surfaces to get the biofilm attached. All slides were cleaned with acetone before soaking in $3.5 \%$ sodium hypochlorite $(\mathrm{V} / \mathrm{V})$ at $75^{\circ} \mathrm{C}$ for $5 \mathrm{~min}$. Then they were rinsed and transferred into $7.0 \mathrm{~g} / \mathrm{l}$ phosphoric acid solution for $5 \mathrm{~min}$. Slides were rinsed in distilled water, air dried and autoclaved at $121{ }^{\circ} \mathrm{C}$ for $15 \mathrm{~min}$ [3]. This cleansing was required to remove fingerprints, oils, grease and other soils that may have been on glass.

Sessile samples were prepared pouring $20 \mathrm{ml}$ of TSB into sterile Coplin jars and vertically dipping sterile slides in; the inoculum with $10^{3} \mathrm{CFU} / \mathrm{ml}$ was performed in each of them and the samples were incubated at $37^{\circ} \mathrm{C}$, without agitation, for 5 days.

\subsection{Bacterial Count Pour Plate}

After 6, 24, 48, 72 and 96 hours since the inoculum, populations in planktonic state were determined by a standard plate count procedure with Tryptone Soya Agar (TSA), incubated at $37^{\circ} \mathrm{C}$ for $48 \mathrm{~h} \mathrm{[4].} \mathrm{At} \mathrm{the} \mathrm{same} \mathrm{times,}$ slides were aseptically removed from the medium and rinsed with sterile distilled water to remove the unattached cells. Then each slide was placed into a test-tube containing $20 \mathrm{ml}$ of sterile saline and sonicated with a $20 \mathrm{~Hz}$ "Vibra Cell" sonicator (SONICS, Newcastle, CT, USA) for 3 min in order to detach and collect the sessile cells. Opportune serial dilutions of the resulting suspensions were enumerated by plating on TSA and incubating at $37^{\circ} \mathrm{C}$ for $48 \mathrm{~h}$.

\subsection{Bacterial Count by Epifluorescence Microscopy}

The methods used were those suggested by Rodriguez et al. [1]. In particular, after 6, 24, 48, 72 and 96 hours since the inoculum, $1 \mathrm{~mL}$ aliquot of Salmonella sp. TSB culture was transferred into a $1.5 \mathrm{ml}$ micro centrifuge tube. The surnatant was discarded after the suspension was centrifuged at $12.000 \mathrm{rpm} / \mathrm{min}$ for $60 \mathrm{~s}$. The pellet was stained in $1 \mathrm{ml}$ of stain solution. Three different stain dyes were used:

- 4',6-diamidino-2-phenylindole (DAPI), $100 \mu \mathrm{g} / \mathrm{ml}$ in sterile deionized water for $1 \mathrm{~h}$;

- 3,6-bis-dimethylamine-acridine (acridine orange), $0.025 \%(\mathrm{w} / \mathrm{V})$ in sterile deionized water for $1 \mathrm{~h}$;

- 5-cyano-2,3-ditolyl tetrazolium chloride (CTC), $0.15 \mathrm{nM}$ in diluted TSB (1:5) for $1 \mathrm{~h}$ in the dark.

All fluorochromes were purchased from Sigma-Aldrich (Milan, Italy); working solutions were prepared immediately before using and sterilized by membrane $(0.2 \mu \mathrm{m}$ pore size) filtration.

After staining incubation time, the cell suspension was centrifuged and the pellet was washed three times in the same solution used for the staining. Finally the pellet was resuspended in $1 \mathrm{~mL}$ of stain solution and $10 \mu \mathrm{l}$ of 
the cell suspension was placed on a glass microscopic slide and air dried at room temperature.

As regard to sessile cells, slides were aseptically removed from the medium, rinsed twice with sterile deionized water and stained with the three different fluorochromes. After $1 \mathrm{~h}$, the slides were rinsed and air dried.

Preparations were examined with the $\times 100$ oil immersion fluorescence objective of a Nikon microscope (NIKON Instruments Inc., NY, USA), equipped with a 50W mercury burner. The filter set combination found to be most effective for successfully viewing all the different stained preparations, consisted of a $365 \mathrm{~nm}$ excitation filter, an emission filter and a $400 \mathrm{~nm}$ cutoff filter. Bacterial cells were counted in a minimum of 10 microscopic fields. Counts were performed in triplicate.

\subsection{Statistical Analysis}

All the experiments were replicated at least twice and the obtained results were expressed as Log CFU/ml and Log CFU/ $\mathrm{cm}^{2}$ for planktonic and sessile cells enumerations, respectively.

The planktonic Salmonella sp. cell load data (average of the repetitions), obtained by the different count methods, were modeled according to the Gompertz equation as modified by Zwietering et al. [5]:

$$
y=k+A \times \exp \left\{-\exp \left[\left(\mu_{\max } \times e / A\right) \times(\lambda-\text { time })+1\right]\right\}
$$

where $k$ is the initial cell load (LogCFU/ml); A, the maximum bacteria growth attained at the stationary phase (LogCFU/ml); $\mu_{\text {max }}$, the maximal growth rate $(\Delta \mathrm{LogCFU} / \mathrm{ml} / \mathrm{h}) ; \lambda$, the lag phase $(\mathrm{h})$.

Differences in sensitivity of the tested methods were examined by an analysis of variance and Tukey test. Only $P$-values $<0.05$ were considered significant.

"Statistica per Windows" software (Statsoft Inc., release 6.0, Tulsa, USA) was used to perform statistical analyses.

\section{Results and Discussion}

After testing several concentrations of fluorochromes (DAPI, acridine orange and CTC) and several incubation times, the highest numbers of bacteria were obtained in the chosen staining conditions. Moreover, in preliminary experiments we optimized conditions for CTC assay detecting that the addition of TSB to the sample intensified the formation of formazane crystals (data not shown).

Figure 1 reports the best fits of the model to experimental data, referring to planktonic Salmonella sp. cell load, estimated by the different count methods. The absolute sensitivity (i.e. the number of planktonic cells counted) significantly differed among the tested methods. It is clear that the standard plate count procedure was the most sensitive method to estimate viable and cultivable planktonic cells, while microscopy enumerations gave significantly lower bacterial counts $(P<0.05)$. After $24 \mathrm{~h}$, the pour plate method performed a cell load about $8.83 \mathrm{LogCFU} / \mathrm{ml}$, instead of $5.83 \mathrm{Log}$ CFU/ml and $7.03 \mathrm{Log}$ CFU/ml, counted using DAPI and acridine orange, respectively. The number of formazan-containing bacteria (CTC) even was significantly lower with respect to all other methods.

Figure 2 shows sessile Salmonella sp. cell loads estimated by the different count methods. After 6 h, microscopy enumerations with DAPI and acridine orange were significantly more sensitive than the other two count methods $(P<0.05)$. Results recorded after 24 hours by microscopy techniques were $\operatorname{similar}(P>0.05)$, but significantly differed from plate count ones. After $48 \mathrm{~h}$ the number of counted cells was relatively similar over time in every tested method.

The enumeration of active bacteria by epifluorescence microscopy is a rapid, simple, low-cost, and high-sensitivity procedure. In this work, we decided to use CTC, a tetrazolium dye, beside DAPI and acridine orange, generally used as fluorochromes. Tetrazolium salts are used as artificial electron acceptors which are reduced within the respiratory chain. This results in the intracellular formation of colored formazans, equivalent to the respiratory activity of cells. In some studies, CTC was introduced to determine the number of metabolically active bacteria in studies of several aquatic environments, including biofilms [1] [6]-[8], but it is still poorly used. Our preliminary experiments demonstrated that the enrichment of samples with TSB intensified the formation of formazane crystals; this is in agreement with the results of Rodriguez et al. [1], who proposed to use CTC for the enumeration of viable bacteria and incubated their samples of marine, ground and waste waters with a nutrient R2A broth added at a ratio 1:2. 


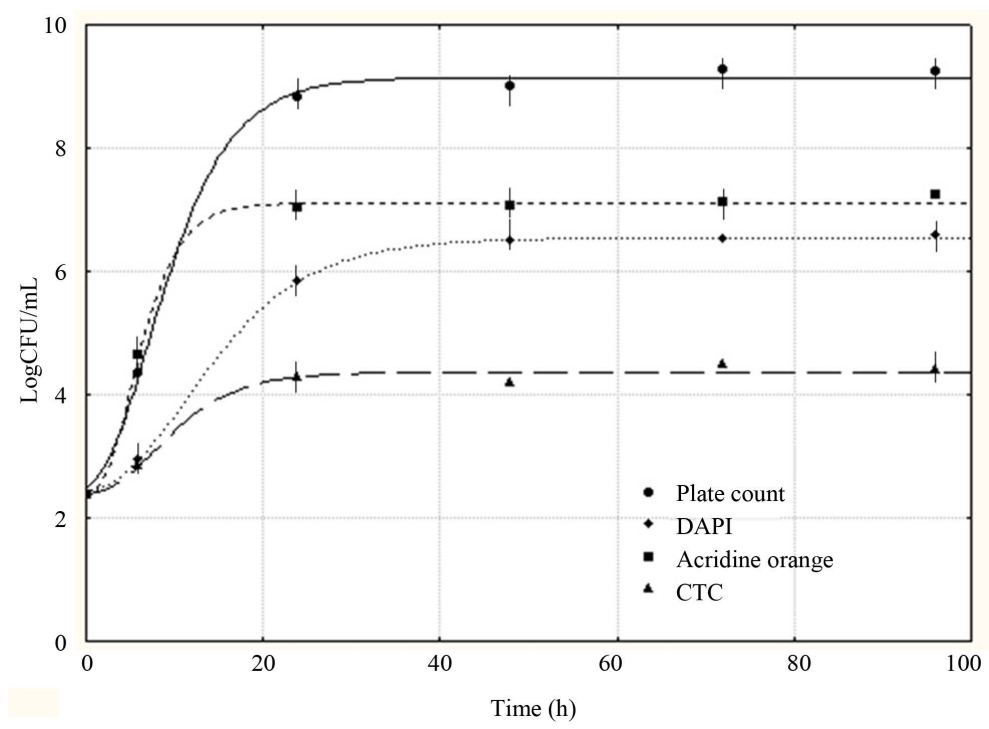

Figure 1. Best fit of modified Gompertz equation to experimental data referring to planktonic Salmonella sp. cell load, estimated by the different tested count methods. The error bars represent the standard deviation of the experimental data.

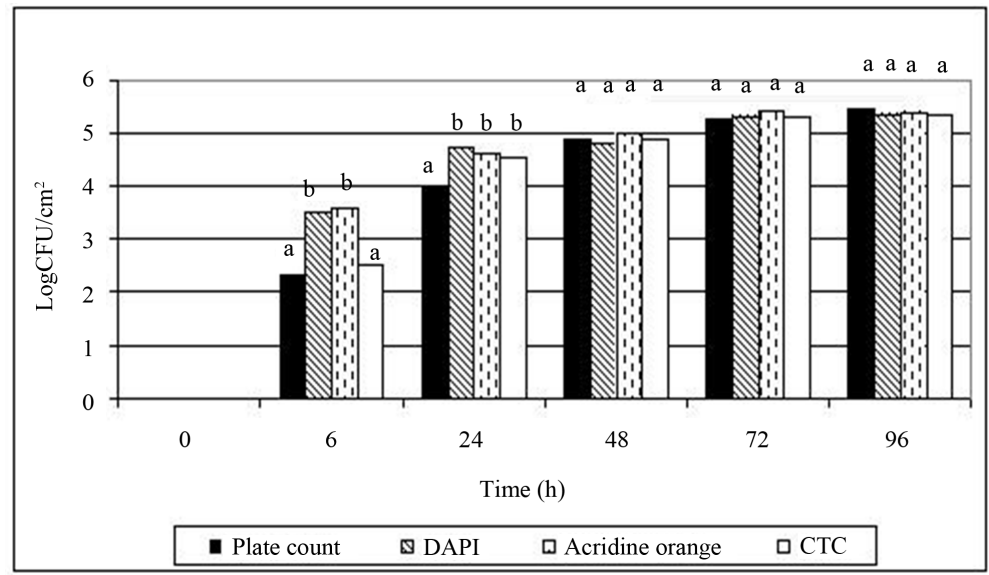

Figure 2. Sessile cell loads estimated by the different tested count methods. Bars with similar superscript do not significantly differ $(P>0.05)$.

The results obtained in our study showed that standard plate count procedure is the most sensitive method to estimate planktonic cells. In fact, all microscopy counts underestimated the planktonics number. The underestimation of microscopy enumerations with DAPI and acridine orange was probably due to the several centrifugation stages used in our procedures. It is possible that during this step, recurring four times, planktonic cells were mechanically damnaged or lost in the surnatant discharges. Nevertheless this hyphotesis cannot explain the results obtained by the CTC assay, because no centrifugation was provided for this procedure. There are other possible explanations for this method result. 1) The assay was not sensitive enough to detect low-rate respiring microorganisms, which might especially be a problem for the detection of small bacteria. 2) Formazane granules are soluble in oil, which is used in immersion microscopy. 3) Bacterial metabolic activity is directly suppressed by the chemical CTC. There are already some indications for a toxic effect of CTC on bacterial cell metabolism in literature, in spite CTC has generally been assumed to be non toxic [2]. In our experiments the detected inhibitory effect of CTC on bacterial metabolism contradicts the usefulness of the CTC assay, and it can be assumed that this method is not suitable for the evaluation of Salmonella sp. planktonic cells.

As regard to sessile Salmonella sp. population, microscopy enumerations proved more useful than plate count 
procedure, showing several advantages: 1) Rapidity (1 - 2 h). 2) Simplicity. 3) Ability to provide useful information concerning microbial activity (or viability) of sessile cells. 4) Possibility to be used to directly observe cells in situ. 5) High sensitivity. Moreover, the CTC assay appeared clearly a useful tool to count cells into a biofilm, without exerting any toxic effect on bacterial cell metabolism. It is well established that bacterial biofilms exhibit an increased resistance to toxic agents than the individual cells grown as planktonics [7] [9]. Probably this recorded resistance to CTC may be attributed to the varied properties associated with the biofilm, including a reduced diffusion of the compound into the structure and/or the production of enzymes degrading toxic substances.

\section{Conclusion}

We have investigated the sensitivity of different procedures in counting bacteria, both as planktonics and sessiles. Our results indicate that standard plate count procedure is the most sensitive method to estimate viable and cultivable planktonic cells. On the other hand, the direct enumeration by epifluorescent microscopy may become an interesting alternative to the traditional techniques in order to count sessile cells.

\section{References}

[1] Rodriguez, G.G., Phipps, D., Ishiguro, K. and Ridgway, H.F. (1992) Use of a Fluorescent Redox Probe for Direct Visualization of Actively Respiring Bacteria. Applied and Environmental Microbiology, 58, 1801-1808.

[2] Epstein, S.S. and Rossel J. (1995) Methodology of in Situ Grazing Experiments: Evaluation of a New Vital Dye for Preparation of Fluorescently Labelled Bacteria. Marine Ecology-Progress Series, 128, 143-150. http://dx.doi.org/10.3354/meps128143

[3] Arizcun, C., Vasseur, C. and Labadie, J.C. (1998) Effect of Several Decontamination Procedures on Listeria monocytogenes Growing in Biofilms. Journal of Food Protection, 61, 731-734.

[4] Vaughan, A., Buzzini, P. and Clementi, F. (2012) Laboratorio Didattico di Microbiologia. Casa Editrice Ambrosiana, Milano.

[5] Zwietering, M.H., Jogenburger, I., Rombouts, F.M. and Van’t Riet, K. (1990) Modelling of the Bacterial Growth Curve. Applied and Environmental Microbiology, 56, 1875-1881.

[6] Coalier, J., Prevost, M. and Rompre, A. (1994) The Optimization and Application of Two Direct Viable Count Methods for Bacteria in Distributed Drinking Water. Canadian Journal of Microbiology, 40, 380-386.

[7] Davies, D. (2003) Understanding Biofilm Resistance to Antibacterial Agents. Nature Reviews Drug Discovery, 2, 114122. http://dx.doi.org/10.1038/nrd1008

[8] Schaule, G., Flemming, H. C. and Ridgway, H. F. (1993) Use of 5-Cyano-2,3-ditolyl tetrazolium Chloride for Quantifying Planktonic and Sessile Respiring Bacteria in Drinking Water. Applied and Environmental Microbiology, 59, 3850-3857.

[9] Leriche, V., Briandet, R. and Carpentier, B. (2003) Ecology of Mixed Biofilms Subjected Daily to a Chlorinated Alkaline Solution: Spatial Distribution of Bacterial Species to Another. Environmental Microbiology, 5, 64-71. http://dx.doi.org/10.1046/j.1462-2920.2003.00394.x 
Scientific Research Publishing (SCIRP) is one of the largest Open Access journal publishers. It is currently publishing more than 200 open access, online, peer-reviewed journals covering a wide range of academic disciplines. SCIRP serves the worldwide academic communities and contributes to the progress and application of science with its publication.

Other selected journals from SCIRP are listed as below. Submit your manuscript to us via either submit@scirp.org or Online Submission Portal.
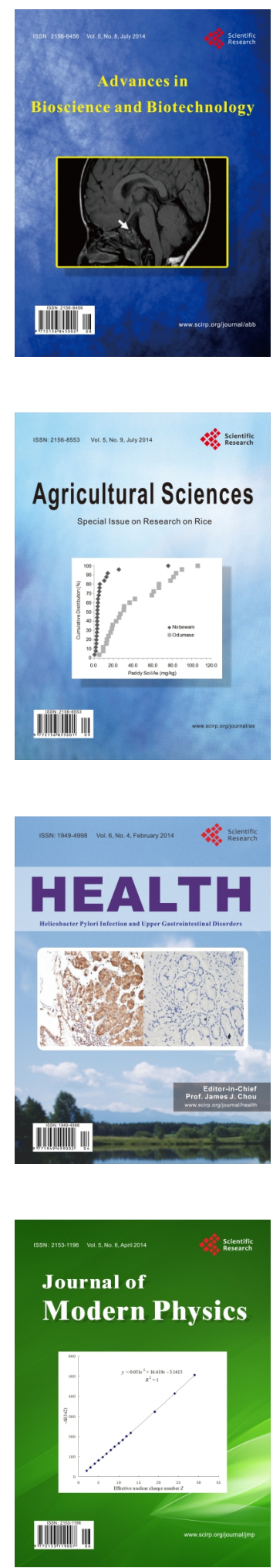
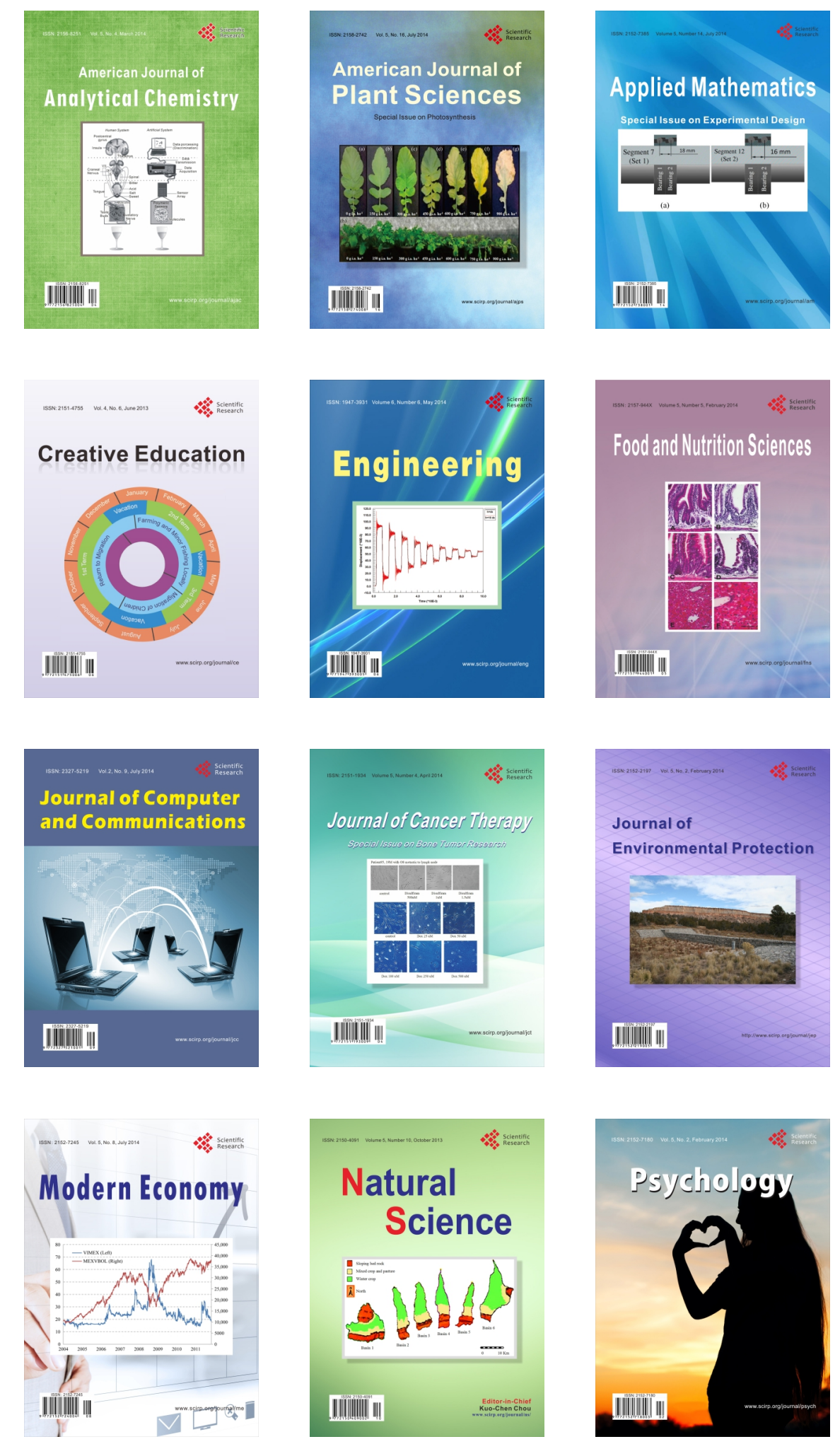